\title{
PERILAKU MASYARAKAT \& ETIKA MEDIA DALAM TAYANGAN INFOTAINMENT DI TELEVISI
}

\author{
Puji Nugroho
}

Email:pj122489@gmail.com

\begin{abstract}
Mass media should meet its institution function including educating, providing information, entertaining and influencing. However, media orientation on rating and capital tend to shape media industry to only full fill entertaining fuction. Infotainment is one of most popular television program in Indonesia that has hight ratting. However, infotainment has problem since it potentionally decrease morality and produce negative character such us opportunism, apathism and hedonism. The study found that infotainment dominate Indonesian tvprogram; infotainment is a potential media comodity in Indonesian broadcasting industry; infotainment has negative content that endanger consumer and society; Indonesian Broadcasting Commition does not has any power to ragulate this program yet.
\end{abstract}

Keywords: People behavior, media ethics and infotainment shows on television

\section{PENDAHULUAN}

Kehidupan manusia tidak dapat terlepas dari peran media massa. Perkembangan teknologi komunikasi dengan berbagai macam inovasi yang menghasilkan berbagai bentuk media massa yang mengisi hidup manusia, salah satunya ialah televisi, yang dapat disebut sebagaimedia massa yang paling berpengaruh dalam kehidupan manusia. Dalam bukunya yang berjudul Amusing Ourselves to Death, Neil Postman (1985) bahkan menyebutkan bahwa televisi memiliki kekuatan untuk menggeser budaya manusia yang sebelumnya didominasi oleh budaya baca-tulis, yang mendorong masyarakat berpikir rasional, menjadi budaya televisual yang hanya menekankan pada tayangan yang menarik dan menghibur penonton. Tesis Postman mengenai dampak televisi bagi perubahan budaya masyarakat tersebut tampak relevan jika kita berkaca pada apa yang dialami masyarakat Indonesia. Seiring dengan munculnya berbagai stasiun televisi swasta yang mengusung berbagai macam konten hiburan, tingkat konsumsi televisi masyarakat Indonesia semakin meningkat hingga kini televisi menjadi media yang paling banyak dikonsumsi oleh konsumen media diIndonesia, sementara tingkat konsumsi media cetak terus menurun (Nielsen, 2009).

Hal ini semakin dipertegas dengan fakta yang dapat dimati bahwa hampir seluruh rumah tangga di Indonesia telah memiliki televisi. Hingga, tidak salah jika kita menyebut bahwa televisi merupakan media yang tidak terpisahkan dari kehidupan sehari-hari masyarakat Indonesia. 
Meluasnya televisi salah satunya disebabkan oleh sifat televisi yang mudah dan murah untuk dikonsumsi. Untuk menikmati konten televisi, seseorang tidak butuh literasi khusus seperti media cetak yang mensyaratkan kemampuan baca. Konsumsi televisi juga dinilai efisien biaya karena seseorang tidak perlu membayar biaya khusus seperti ketika menonton film di bioskop. Kelebihan utama televisi terletak pada sifatnya yang audio-visual sehingga tampilannya lebih nyata dan menarik, Selain itu, televisi juga tidak membutuhkan tempat dan mobilitas tertentu. Seseorang hanya perlu duduk nyaman, santai, dan tinggal menyalakan televisi jika ingin menonton tayangan hiburan di dalamnya. Kehadiran televisi di rumah telah menjelma sebagai bagian dari 'anggota keluarga tak diundang' yang seolah-olah memberi asupan kebutuhan penontonnya akan berbagai tayangan yang menghibur. Salah satu tayangan hiburan yang paling marak mewarnai televisi Indonesia ialah tayangan infotainment.

Dari latar belakang diatas maka timbul persoalan dari tayangan infotainment yaitu bagaimana masyarakat melihat tayangan beritaberita infotainment dan bagaimana dampaknya dalam masyarakat setelah melihat acara infotainment tersebut? Apakah infotainment bisa merubah perilaku etika dalam kehidupan masyarakat yang dimunculkan oleh media?

\section{PEMBAHASAN}

\section{Infotainment}

Kini hampir tayang setiap hari, sepanjang waktu dari pagi hingga malam, di hampir seluruh stasiun televisi nasional. Sebut saja Silet, Cek dan Ricek, Go Spot, serta Kabar-Kabari di RCTI, Insert diTransTV, Was-was dan Hot Shot di SCTV, KISS di Indosiar, Espresso di ANTV, Info Selebritis di Global TV, dan bahkan acaraacara berita (news) terkadang menampilkan gaya infotainment.

Tingginya intensitas penayangannya di televisi membuat infotainment telah menjelma ritual sosial bagi masyarakat penonton televisi di Indonesia. Padahal jika dilihat beberapa tahun ke belakang, di awal tahun 2000-an, infotainment belum terlalu menjamur seperti saat ini. Pada awalnya, infotainment hanya diplot sebagai sajian selingan berita-berita ringan untuk melengkapi konten berita hard news serta berbagai drama sinetron. Namun, ternyata konsumen media menggemari infotainment yang menyuguhkan gosip seputar selebritis dan lifestyle orang-orang terkenal. Berbagai indikator seperti rating televisi maupun tumbuhnya kuantitas acara infotainment menunjukkan perkembangan pesat infotainment sebagai salah satu acara televisi yang paling menjual bagi pasar konsumen media di Indonesia.

Oleh karena itulah, maraknya infotainment di berbagai stasiun televisi Indonesia di tahun-tahun belakangan ini merupakan fenomena yang menarik dikaji dari kerangka industri media massa. Logika industri media, terutama komodifikasi, standarisasi, dan reduksi substansi hiburan dinilai mampu menjelaskan bagaimana infotainment mampu menjadi salah satu komoditas utama acara televisi yang mampu menarik minat pasaryang sedemikian besar untuk terus mengkonsumsi acara trivial.

\section{Perkembangan Infotainment}

Terminologi infotainment pertama kali dikenal dalam indutri televisi Amerika Serikat pada tahun 1960-an (Gordon, 1999). Namun, seperti telah disinggung sebelumnya, format tayangan infotainment dipahami secara berbeda di negara asalnya, Amerika Serikat, dan di Indonesia. Di Amerika Serikat, infotainment ialah tayangan berita (news) yang dikemas dalam format hiburan. Awalnya, acara news hanya dikemas secara serius, elegan, dan terdiri dari hard news, soft news, dan feature.

Seiring tayangnya program-program berita yang berkesan serius, stasiun televisi merasa 
bahwa untuk mendongkrak rating siaran. publik membutuhkan pengemasan berita secara lebih entertaining atau menghibur. Hiburan dinilai penting karena mengingat konteks sosial di Amerika Serikat pada saat itu bahwa televisi dinikmati oleh kelas-kelas pekerja ketika dia berada di rumah, sehingga yang diharapkan ialah kontentayangan yang ringan dan tidak lagi menuntut dia untuk berpikir secara serius. Salah satu acara infotainment generasi pertama adalah acara berita Sixty Minutes di CBS pada tahun 1968 yang mengemas berita laporan investigatif dengan cara yang dramatis melalui figure hostnya, Don Hewitt.

Sixty Minutes ternyata mendapat tanggapan positif dari publik, menjadi sangat terkenal dan mencatat rating yang tinggi. Oleh karena itu, format penyampaian berita ini terus diproduksi dan menjadi contoh bagi stasiun televisi lain untuk memproduksi acara-acara berita yang serupa. Dalam perkembangannya, isi berita yang ditayangkan dalam acara infotainment tidak hanya berupa berita-berita politik dan sesuatu yang menyangkut kepentingan publik, tetapi juga lebih mengarah kehuman interest, juga skandal public figure.

Perubahan konsep berita televisi ini juga diikuti oleh format berita di surat kabar yang dipelopori oleh Koran USA Today. Hingga pada akhirnya, pada tahun 1970-an, entertainment atau hiburan dianggap sebagai salah satu mainstream berita. Berbeda dengan Amerika yang diawali oleh televisi, kelahiran infotainment di Indonesia justru dilahirkan oleh media cetak. Sebelum demokratisasi dan kebebasan pers lahir dan istilah infotainment belum akrab didengar, di media massa umum telah sering dimuat berita soal artis dan kehidupan sehari-harinya, tetapi hanya mengisi di rubrik-rubrik khusus, antara lain: seni, budaya, hiburan, gaya hidup atau tokoh. Porsi pemberitaanya kecil dan menjadi selingan untuk mengambil jeda dari liputan yang serius. Dalam perkembangannya, rubrik hiburan tersebut kemudian menjadi salah satu rubrik favorit yang kehadirannya dinantikan para pembaca, bahkan 'mengalahkan' rubrik utama yang mengangkat isu-isu serius. Melihat animo masyarakat yang begitu besar terhadap informasi hiburan tersebut, maka munculah ide untuk mengangkat tema hiburan tersebut menjadi sebuah tabloid. Pada saat itu waktu memasuki era reformasi di mana kebebasan pers didengungkan dan pendirian surat kabar atau media pers tidak butuh surat izin. Longgarnya regulasi mendorong banyak para pengusaha untuk membuat media yang mudah, murah, teteapi diminati pasar. Mereka mendirikan tabloid khusus kehidupan kaum selebritis dan merekrut para wartawan hiburan.

Dalam kurun waktu satu tahun, tabloid dan majalah hiburan pun mulai menjamur dan membanjiri pasar media cetak di Indonesia. yaitu tabloid hiburan "Gramedia" dan "Monitor" pada tahun 1980-an yang khusus memuat berita-berita ringan mengenai selebritis. Kesuksesan yang diraih oleh tabloid maupun majalah hiburan tersebut kemudian menginspirasi pengusaha media, khususnya televisi, untuk mengangkat tema hiburan tersebut menjadi salah satu mata acara mereka. Sebagian stasiun televisi kemudian mencoba untuk memproduksi tayangan hiburan tersebut secara mandiri (in house) dan sebagian lagi memilih untuk membeli tayangan hiburan tersebut dari rumah produksi (production house). Format berita hiburan yang dimuat di tabloid ini kemudain diadopsi oleh Ilham Bintang, pemilik PT Bintang Advis Multimedia, dengan memproduksi acara"Cek \& Ricek" di tahun1997. Acara inilah yang menjadi pelopor lahirnya tayangan infotainment yang menjual berita mengenai kehidupan artis, yang cenderung sensasional dan trivial hingga akhirnya tayangan ini identik dengan berita gosip artis. Setelah itu, barulah muncul istilah infotainment (informasi dan entertainment) sebagai trademark dari tayangan yang berisikan informasi hiburan. 
Infotainment pun kembali menjamur di stasiun-stasiun televisi Indonesia, dari yang awalnya hanya satu kali penayangan sehari kini menjadi tiga kali penayangan dalam sehari. Tumbuhnya tayangan infotainment di televisi didorong oleh prospek ekonomi yang menjanjikan: biaya produksi murah dan banyak diminati pasar. Hingga saat ini di tahun 2011, di Indonesia telah ada kurang lebih 40 judul infotainment yang memenuhi televisi dengaan tayang kurang lebih 14 jam sehari dan mampu menyedot sekitar 10 juta penonton (VivaNews, 27 Desember 2009).

Infotainment di Indonesia: Pasar Potensial

Bagi masyarakat Indonesia, televisi sudah menjadi bagian tak terpisahkan yang mewarnai kehidupan sehari-hari. Berdasarkan data yang dilansir dari Nielsen mengenai pola konsumsi media di Indonesia pada tahun 2005-2009, diketahui masyarakat Indonesia menghabiskan sebagian besar waktunya untuk menggunakan dan mengkonsumsi media, baik cetak, siar,maupun online. Di antara berbagai media tersebut, televisi menempati peringkat pertama sebagai media yang paling banyak dikonsumsi, dengan tingkat konsumsi sebesar $94 \%$ dari total seluruh konsumsi media oleh penduduk Indonesia (Nielsen Consumer Insights, 2009). Melihat tingginya tingkat konsumi televisi oleh masyarakat Indonesia tersebut, tak ayal bahwa televisi disebut pula sebagai anggota keluarga yang tak diundang yang memberi pengaruh besar bagi kehidupan khalayaknya. Kuatnya budaya menonton yang dibentuk televisi ditambah dengan efisiensi finansial yang dibawa televisi membuat acara-acaratelevisi menjadi suatu kebutuhan tersendiri bagi masyarakat Indonesia. Kondisi tersebut menyebabkan industri media televisi memiliki kekuatan untuk membentuk selera masyarakat dan mempengaruhi kesadaran pemirsanya dengan cara menggambarkan realitas yang terkonstruksi sehingga dapat menjadi sarana escapism bagi pemirsanya (Gerbner, 1982).

\section{Biaya Murah, Rating Tinggi}

Salah satu tayangan yang paling mampu merengkuh pasar dalam skala massif ialah tayangan hiburan. Hiburan menjadi dasar ideologi bagi segala konten yang disajikan di televisi karena orientasinya ialah untuk menjaring rating sebesarbesarnya. Begitu pula dengan yang terjadi pada tayangan infotainment. Dalam industri televisi, infotainment termasuk dalam daftar acara yang mampu mendongkrak rating (Nielsen, 2009). Seorang petinggi dari PT Bintang Advis Multimedia, perusahaan yang mempelopori diadopsinya infotainment menjadi tayangan televisi, menyebutkan bahwa infotainment sangat menguntungkan produser karena 'ratingnya tinggi dan return-nya cepat' (Firdaus, 2009). Artinya, dari segi produksi, infotainment merupakan tayangan efisien dari segi finansial karena tidak membutuhkan biaya produksi yang besar. Dari segi konten, program ini tidak terlalu membutuhkan polesan dalam penyampaiannya. Dalam penayangannya pun tidak terlalu membutuhkan banyak property atau kecanggihan teknologi tertentu. Karena konsepnya adalah seolah-olah menyajikan kehidupan aktual sang artis atau public figure, maka semakin natural cara penyampaiannya maka akan semakin menumbuhkan kepercayaan pemirsa. Meskipun materi yang dibutuhkan untuk penayangan adalah rekaman natural atau wawancara dengan selebritis, tayangan infotainment seringkali menambah efek sensasional untuk mendongkrak rating lebih tinggi. Sensasionalitas berita dihadirkan dengancara penyuntingan gambar yang memberikan efek visual, pembawaan host yang memancing keingintahuan pemirsa dan terkadang diiringi komentar-komentar atau celetukan yang menyindir dan memanaskan skandal sang selebritis.

Dramatisasi visual tersebut tentunya dilakukan dengan orientasi rating tayangan yang akhirnya meningkatkan pemasukan iklan. Semakin sensasional dan kontroversial informasi 
yang disajikan, maka semakin dramatis pengemasan yang dilakukan, dan semakin tinggi pula rating yang akan dicapai. Hal ini terbukti ketika rating tayangan infotainment mampu meroket selama pemberitaan video porno Ariel Peterpan-Luna Maya-Cut Tari yang sempat membuat publik heboh (Koran Tempo, 10 Juni 2010). Tidak hanya berita skandal yang sensasional, berita kesedihan artis pun menjadi komoditas yang menjual bagi infotainment.

Contoh nyata adalah pada saat pemberitaan tentang kecelakaan Virgini Anggraini, istri pedangdut Saiful Jamil. Berikut merupakan kutipan dari Tabloid Bintang (5 Sepetmber 2011). "BERITA kematian Virginia Anggraeni, istri Saipul Jamil menyita perhatian masyarakat luas, khususnya pemirsa televisi. Hal ini bisa dilihat dari rating infotainment yang naik drastis ketika menyiarkan kecelakaan maut yang menimpa Virginia pada Sabtu (3/9). Menurut data Nielsen, pada hari Sabtu (3/9) lalu infotainment Investigasi Selebriti yang tayang di Trans TV mampu menduduki peringkat 2 dengan TVR 4,3 dan share 30 persen. Angka yang istimewa untuk tayangan infotainment. Padahal untuk tayangan Jumat (2/9), Investigasi Selebriti hanya meraih posisi 40 dengan TVR 1,8 dan share 11,8 . Hari Minggu (4/9), prestasi serupa dicetak Hot Shot. Infotainment tayangan SCTV ini berada di posisi 2 dengan TVR 5 dan share 32,7. Sehari sebelumnya, infotainment yang tayang jam 9 pagi ini berada di anak tangga 24 dengan TVR 2,6 dan share 18,1. Masih di hari Minggu, Intens melejit ke posisi 3 dengan TVR 3,7 dan share 23,8. Hari Sabtu, saat belum membahas kecelakaan Virginia, infotainment milik RCTI ini ada di peringkat 49 dengan TVR 1,9 dan share 13,2. "Dengan melihat lonjakan rating tersebut, tak ayal berbagai infotainment terus berlombalomba menyajikan informasi yang dramatis dan sensasional mengenai berita-berita yang menyangkut kehidupan artis dan bahkan justru mengeksploitasi kisah-kisah artis tersebut.

\section{Infotainment Dalam Logika Industrialisasi Media}

Seperti yang telah disebutkan di atas, kemunculan tayangan infotainment di Indonesia diawali oleh rubrik hiburan di media cetak sebagai selingan dari berita serius, kemudian diangkat menjadi tabloid hiburan tersendiri, dan diadopsi menjadi tayangan hiburan di televisi. Seiring perkembangannya, infotainment menjadi suatu genre tersendiri yang ada di hampir seluruh stasiun TV nasional dan dianggap sebagai salah satu jenis hiburan populer yang paling menjual. Maraknya infotainment sebagai tayangan hiburan populer ini dapat dilihat dari kaca mata industri media sebagai dampak industrialisasi media yang perumusan kontennya berorientasi pada pasar dan perolehan keuntungan maksimal. Dalam kerangka industri media, terdapat empat konsep pokok yang mampu menjelaskan fenomena maraknya infotainment, terutama dalam posisinya sebagai produk hiburan populer di tengah industrialisasi media televisi. Ketiga konsep tersebut yaitu Komodifikasi Media, Standardisasi Format Tayangan, dan Reduksi Substansi, yang selanjutnya melahirkanbeberapa implikasi sosial bagi audiens dan masyarakat secara umum.

\section{Komodifikasi Media}

Dalam tesis industri budaya Adorno, disebutkan bahwa sebagai salah satu produk budaya, media menjadi suatu objek yang diperjual belikan atau dianggap sebagai komoditas. Komodifikasi media tersebut diatur dalam prinsip nilai tukar, bukan nilai gunanya, sehingga apa yang paling bernilai untuk ditampilkan di media adalah yang paling mampu menarik masyarakat, bukan berdasarkan muatan apa yang paling berguna (Adorno, 1954). Sedangkan Vincent Mosco, dalam bukunya The Political Economy of Communication (2009: 132), mendefinisikan komodifikasi sebagai proses mengubah nilai pada suatu produk yang tadinya hanya memiliki nilai 
guna kemudian menjadi nilai tukar (nilai jual) di mana nilai kebutuhan atas produk ini ditentukan lewat harga yang sudah dirancang oleh produsen. Begitu pula halnya dengan tayangan infotainment yang menjadi salah satu komoditas media. Sebagai dampak industrialisasi media, infotainment juga diposisikan sebagai salah satu sumber pendapatan yang paling menghasilkan nilai tukar.

Infotainment berkembang menjadi komoditas media yang menjanjikan karena yang terjadi bukan hanya komodifikasi untuk mendapatkan nilai tukar yang bertambah (surplus value), tapi juga karena pesan yang disampaikan mengandung simbol dan citra yang bisa dimanfaatkan untuk mengkonstruksi realitas yang diterima di benak penonton sebagai penerima pesan. Masalah makna atau nilai guna yang dimuat dalam infotainment tidak lagi menjadi hal yang penting karena dasar logika yang digunakan ialah bagaimana media bisa menayangkan acara yang paling menghibur, paling menarik animo masyarakat, bukan apa yang mendidik masyarakat. Dalam industri komunikasi sendiri, dikenal tiga jenis komodifikasi, yaitu komodifikasi konten, komodifikasi audiens, dan komodifikasi buruh (Mosco, 2009:135-139), dan ketiga jenis komodifikasi ini dapat ditemukan dalam fenomena tumbuhnya infotainment sebagai komoditas dalam industri komunikasi.

Pertama, komodifikasi konten. Menurut Mosco (2009), komodifikasi konten merujuk pada proses transformasi pesan dari hanya sekedar informasi menjadi sistem pemikiran penuh makna dalam bentuk produk yang dapat dipasarkan. Artinya, terjadi pengolahan konten media agar disukai oleh publik meski pada dasarnya konten tersebut tidak dibutuhkan oleh publik. Dalam tayangan infotainment, komodifikasi konten dilakukan dengan cara menciptakan dramatisasi informasi mengenai selebritis sehingga informasi yang sebenarnya tidak memiliki signifikansi bagi masyarakat dapat menarik minat publik untuk menyaksikan karena timbul rasa ingin tahu terhadap segala informasi mengenai selebritis tersebut, terutama ketika sifatnya sensasional dan terus-menerus digali dan ditayangkan. Contoh yang jelas tampak ialah komodifikasi terhadap kasus kecelakaan Virginia Anggraini, istri pedangdut Saipul Jamil yang menghiasi layar televisi cukup lama, selama kurang lebih 2 minggu, karena infotainment berusaha membesar-besarkan segala macam hal mengenai kecelakaan tersebut. Mulai dari kesedihan Saipul dan keluarga yang dieksploitasi, komentar orangorang terdekat, kehidupan rumah tangga mereka sebelum Virginia meninggal, firasat yang diperoleh sebelum peristiwa kecelakaan, sampai mitos dan mistis tentang tol Cipularang yang menjadi tempat kejadian. Segala informasi tersebut pada dasarnya merupakan informasi yang tidak berpengaruh bagi publik. Namun, karena media mengekspose dari segala sisi, berita tersebut turut mempengaruhi kesadaran dan membuat pemirsa terus ingin tahu.

Kedua, komodifikasi audiens yang berarti menempatkan audiens atau penonton sebagai salah satu komoditas utama industri media (Mosco, 2009:136). Komodfikasi audiens mengandung proses pengolahan isi media untuk dijual melalui pengiklan baru ke audiens. Oleh karena itu, audiens yang menjadi khalayak infotainment tersebut menjadi tolak ukur tingginya nilai tukar infotainment tersebut sebagai salah satu produk media melalui tingginya angka rating. Pengukuran banyaknya pemirsa yang menonton menjadi salah satu indikator keberhasilan suatu tayangan infotainment yang kemudian dijual ke pihak pengiklan agar mau memasang iklan di tayangan tersebut. Dengan kata lain, audiens sebenarnya menjadi salah satu 'komoditas' andalan media untuk memperoleh keuntungan optimal. Contoh komodifikasi audiens dapat dilihat dari tayangan infotainment 'Insert'dan 'Insert Investigasi' yang memperoleh rating cukup tinggi di antara berbagai judul 
infotainment lain.

Insert juga memiliki polling segmen untuk mengkur tingginya animo masyarakat terhadap berita-berita tertentu yang sedang heboh sehingga Insert dapat menayangkan berita yang paling disukai dan pada jam itu, rate iklan pun dijual dengan harga lebih. Selain itu, melihat cukup tingginya audiens yang menyaksikan acara ini, Insert pun memanfaatkan jam tayangnya untuk mengiklankan suatu produk yang biasanya diiringi dengan testimonial selebritis yang diliput. Dengan demikian, Insert dapat menggandakan pemasukan iklannya.

Ketiga, komodifikasi buruh yang menurut Mosco (2009:139) dapat dilakukan melalui dua cara: mengatur fleksibilitas dan kontrol atas pekerja dan "menjual" pekerja media untuk meningkatkan nilai tukar dari isi pesan media. Komodifikasi pekerja mengandung adanya eksploitasi keahlian dan jam kerja para pekerja dengan menjadikannya sebagai komoditas dan menukarnya dengan upah dan gaji. Dalam hal infotainment, komodifikasi buruh cara pertama ini terjadi pada pekerja produksi acara yang selalu berlomba-lomba menayangkan liputan artis secara lengkap dan detil karena ketatnya persaingan agar rating tidak jeblok. Sebagai contoh, seorang penulis naskah di rumah produksi Kroscek (Trans TV), menyebutkan bahwa jam kerja wartawan infotainment bisa mencapai jam 3 pagi setiap harinya (Firdaus, 2009). Jam tayang infotainment pun bukan lagi hanya ditujukan bagi ibu-ibu rumah tangga atau saat santai, tapi nyaris 24 jam sehingga para kru dan pekerja dituntut kerja ekstra keras, menggali lebih detil dan menjadi yang pertama dalam menyiarkan gosip. Sedangkan cara kedua dilakukan dengan memanfaatkan publik figur tertentu sebagai 'ikon' media tersebut yang dapat menarik publik untuk mengkonsumsi. Misalnya saja Silet yang menjual 'ikon' Feni Rose sebagai host yang dramatis.

\section{Standardisasi Format}

Standardisasi merupakan upaya penyeragaman berdasarkan suatu formulasi spesifik untuk mencapai tujuan tertentu, dalam hal ini ialah mengkonstruksi respon konsumen budaya (Adorno, dalam Strinati, 2007). Keseragaman ini berangkat dari logika industrialisasi budaya yang percaya bahwa sebagai salah satu komoditas industri media, infotainment juga harus berevolusi dan berkembang untuk menemukan format terbaik yang dapat menjaring pasar sebesar-besarnya. Formulasi terbaik yang berhasil di pasar tersebut selanjutnya akan menjadi acuan bagi produsen agar lebih mudah memproduksi suatu tayangan secara masif sesuai dengan rumusan yang telah terukur keberhasilannya. Dalam produksi infotainment, dapat diidentifikasi adanya standarisasi tertentu, mulai dari segmentasi audiens, format tayangan, pengemasan acara, ikon yang diangkat, gaya penyampaian, konten informasi yang dimuat, hingga jam dan durasi tayang. Hal ini bisa dilihat dari perkembangan infotainment yang awalnya ialah suatu rubrik hiburan kemudian menjadi tayangan informasi seputar selebritis. Formulasi yang diawali oleh tayangan Cek n Ricek di RCTI tersebut kemudian sukses laku di pasaran. Oleh karena itulah, mulai muncul tayangan lain yang serupa, menghadirkan seorang sosok pembawa acara wanita, dengan rekaman wawancara pertanyaan ringan dengan sang artis, dan lebih menjual tampilan visual, atau rekaman gambar, yang didramatisir dengan berbagai efek visual seperti repetisi dan penekanan gambar, serta diiringi narasi yang membuat penonton penasaran. Singkat kata, formulasi tayangan infotainment ialah seperti acara yang mengajak penonton bergosip. Perkembangan infotainment dengan format gossip seperti sesungguhnya menunjukkan adanya pembentukan sub-genre infotainment. Genre secara konseptual didefinisikan sebagai alat praktis untuk membantu media massa memproduksi secara konsisten dan efisien, sesuai dengan ekspektasi target audiens-nya (Creeber, 
2001). Adanya format obrolan dalam infotainment untuk wanita menunjukkan bahwa standardisasi tayangan tersebut pun dikhususkan kepada identitas kolektif tertentu sehingga memudahkan produser acara televisi untuk memproduksi infotainment sesuai dengan struktur naratif yang telah menjadi pakem industri dan disesuaikan dengan karakter kultur wanita yang dianggap menyukai gossip, berita ringan dan trivial, juga skandal-skandal sensasional. Oleh karena itulah, dari segi segmentasi audiens, hampir seluruh tayangan infotainment ditujukan untuk wanita.

\section{Reduksi Substansi: Sebuah Pemikiran dari Sisi Etika Komunikas}

Menurut McQuail, sebagaimana media lain, televisi memiliki empat fungsi utama, yaitu: pendidikan, sosial kontrol, informasi, dan hiburan (McQuail, 2005). Akan tetapi, dalam bukunya Amusing Ourselves to Death (1985), Neil Postman menyebutkan bahwa bagi masyarakat modern, televisi hanya melayani fungsi hiburan secara dominan dan cenderung mengabaikan fungsifungsi lainnya. Jika suatu tayangan televisi pun memiliki fungsi sosial, pendidikan, atau informasional, acara yang ditayangkan di televisi itu pun pasti disisipi oleh unsur-unsur yang menghibur. Argumen Postman ini beranjak dari logika industrialisasi yang menitikberatkan pada komodifikasi yaitu yang terpenting dari suatu komoditas ialah seberapa besar produk tersebut disukai (nilai tukar), bukan seberapa besar manfaat produk tersebut (nilai guna). Oleh karena itulah, hiburan menjadi alat utama untuk menarik publik. Menurut Postman (1985), hiburan merupakan supra-ideologi dari seluruh diskursus publik di televisi. Karenanya, unsur hiburan yang menyisipi segala tayangan televisi tersebut mempengaruhi hampir seluruh aspek kehidupan manusia, sebagai konsumen tayangan televisi tersebut. Tayangan televisi yang dipenuhi segala unsur hiburan tersebut mempengaruhi cara pandang, cara berpikir, cara bicara, hingga cara orang memilih sikap. Dalam format talkshow, hiburan merupakan sesuatu yang dikultuskan karena menyediakan ruang bagi audiens untuk melepaskan diri dari realita yang membuat mereka tertekan dan kondisi kehidupan sehari-hari yang tidak menyenangkan. Acara infotainment menempatkan kehidupan sang narasumber yang diundang sebagai contoh hidup ideal yang dapat menghibur audiens. Jika diklasifikasikan menurut tipologi genre televisi yang dirumuskan oleh Berger (1992), tayangan infotainment tergolong dalam jenis acara aktualitas. Tipe aktualitas menekankan pada berita, dokumenter, atau reality show.

Di tengah industrialisasi media, proses komodifikasi audiens mendorong segala produk televisi disetir oleh rating sehingga segala tayangan televisi dipenuhi oleh aneka ragam hiburan karena mereka percaya bahwa yang paling disukai masyarakat dan paling laku dijual di pasaran adalah sesuatu yang menghibur. Begitu pula, dengan tayangan infotainment di televisi. Infotainment merupakan acara televisi yang tidak dapat dilepaskan dari unsur hiburan. Dengan memanfaatkan resistensi dan kepenatan publik terhadap berita-berita serius yang mengusung isu-isu ekonomi, sosial, politik, infotainment membanjiri publik dengan memberikan tayangan yang mampu mengalihkan kepenatan publik. Infotainment menyuguhkan realita yang lain, realita 'sang bintang idola' yang bisa turut dilihat dan dirasakan publik.

Reduksi substansi-substansi yang penting dan berdampak bagi publik juga dilakukan infotainment dengan cara trivialisasi dan tabloidisasi informasi. Trivialisasi dapat dilihat dari muatan berita seputar selebritis yang diangkat ke layar telvisi bukanlah informasi inspiratif seperti kisah perjuangan artis menuju sukses tetapi lebih kepada informasi ramah-tamah mulai dari gaya rambut baru, pacar baru, rumah baru, atau perkawinan, perceraian, perselingkuhan, sampai pertengkaran keluarga. Indikasi tablodisasi 
konten terlihat dari alur cerita para selebritis dikemas begitu dramatis oleh infotainment dengan ketegangan menyamai film thriller, dan di lain waktu infotainment menampilkan kisah artis secara mengharu-biru dengan kucuran isak tangis ala epik drama.

Penekanan utama pada rating melalui trivialisasi dan tabloidisasi, di satu sisi bukan hanya mereduksi sebuah subtansi fungsi media, dari yang sejatinya menurut Schramn berfungsi sebagai; mendidik, informasi, hiburan dan mempengaruhi, namun pada fenomena tayangan infotainment tersebut hanya tercakup fungsi menghibur saja, serta masih jauh dari fungsi media massa secara idealistik, di tengah masyarakat Indonesia yang masih memerlukan informasi berat lainnya terkait sosial politik ekonomi dan budaya. Penekanan rating secara membabi buta tersebut di satu sisi juga akan mereduksi nilai-nilai etika yang seharusnya disampaikan kepada masyarakat secara kepantasan dan kepatutan. Aspek kepantasan dan kepatutan ini sangat erat berkaitan moralitas, di mana dalam ini pendekatan ekonomi politik media, setidaknya masih disertai oleh adanya rujukan nurani manusia. Hal ini sebagaimana kata Karimah dan Wahyudin (2010:63) bahwa norma moral berhubungan dengan manusia sebagai pribadi. Pendukung dari norma ini adalah hati nurani manusia. Hati nurani ini sangat berperan dalam perilaku lahiriah manusia. Pelanggaran terhadap norma ini adalah penyesalan, karena tidak ada kekuasaan dari luar diri manusia yang mengancam. Tujuannya adalah penyempurnaan manusia sebagai manusia. Sebagai contoh, kasus video porno yang melibatkan Ariel (Peterpan) dengan beberapa belasan wanita selebiritis yang santer beredar di masyarakat. Dari sisi substansi, perilaku seks Ariel dengan beberapa selebritis merupakan domian pribadi, namun ketika video tersebut "bocor" ke masyarakat, maka hal tersebut sudah masuk ranah hukum, di mana pelaku tindak pidananya adalah penyebar video pornografi.
Namun pada proses yang berlangsung, justru Ariel terseret ke dalam ranah pidana, karena pasal kelalaian, begitu pula teknisi laptop milik Ariel sebagai penyebar video pornografi, terjerat kemudian terpidana. Permasalahan di sini adalah dengan dipastikannya bahwa secara incracht Ariel dinyatakan bersalah, seharusnya pihak televisi tidak berusaha untuk mem-blow-up pemberitaan Ariel sekitar pornografi, bukan juga dengan membela perilaku seksual Ariel, walaupun itu ranah pribadi. Namun karena Ariel termasuk public figure, maka pelanggaran etika sekecil apa pun pihak televisi yang suka tayangan infotainment dituntut untuk memiliki kepekaan nurani, karena perilaku seks bebas yang dilakukan Ariel sudah menyalahi norma sosial dan termasuk pelanggaran etika sosial yang berat pada masyarakat harmoni seperti di Indonesia ini. Dalam kasus tayangan infotainment Ariel tersebut, media dianggap sudah menyalahi etika normatif. Menurut Karimah dan Wahyudin (2010:63) etika normatifmerupakan suatu ilmu yang mengadakan ukuran-ukuran atau norma-norma yang dapat dipakai untuk menanggap atau menilai perbuatan atau tingkah laku seseorang dalam masyarakat. Etika normatif ini berusaha mencari ukran umum bagi baik an buruknya tingkah laku, sehingga terkait dengan perlu tidaknya hal tersebut ditayangkan di televisi sebagai salah satu wujud dari fungsi media massa yaitu fungsi mendidik masyarakat.

Alasan dan pembenaran yang diberikan oleh para pelaku industri infotainment yang selama ini bernaung dalam isme struktur ekonomi politik neoliberal menurut Sunarto (2009:85) merupakan desakan serta tindakan para aktor sosial di balik proses liberalisasi media di tanah air pasca Orde Baru, secara jelas telah didasarkan atas dogma neoliberalisme yang antara lain mengklaim bahwa "the greater the play of the market forces, the greater the freedom of the press; thegreater the freedom of the press, the greater the freedom of the audience choice". 
Dogma semacam inilah yang diyakini pemilik modal media dalam melakukan aksi bisnisnya yang seolah hanya bersandarkan pada kebebasan pers yang berdimensi pada audience sebagai pemegang amanah demokratisasi. Namun, juga perlu disadari bahwa dengan banjirnya informasi dari infotainment yang tayang hampir setiap saat si setiap stasiun TV menyebabkan masyarakat menjadi masyarakat yang tidak rasional karena disuguhi realitas infotainment yang telah terdistorsi. Hal ini persis seperti yang dikatakan Postman (1985) tentang dampak budaya televisual yang mengedepankan hiburan pada akhirnya justru meredam rasionalitas karena hiburan di televisi tidak membiasakan masyarakat untuk berpikir, dan yang lebih terekspolitasi justru emosi dan perasaan yang akan dipacu untuk mengikuti alur pemberitaan. Pada akhirnya, tayangan hiburan, khususnya infotainment justru menciptakan masyarakat kontra produktif karena ketiadaan informasi yang rasional.

\section{PENUTUP}

Dari uraian di atas, dapat disimpulkan bahwa infotainment merupakan salah satu tayangan hiburan yang menjadi produk andalan media televisi nasional, yang terbukti dari puluhan judul infotainment yang menghiasi hampir seluruh stasiun televisi nasional, dan ditayangkan hampir 24 jam sehari. Perkembangan infotainment tidak terjadi begitu saja hingga menjadi sangat marak seperti sekarang.

Awalnya, informasi hiburan hadir dalam media cetak sebagai salah satu rubric selingan yang sangat diminati masyarakat di tengah beritaberita yang serius. Selanjutnya, didorong oleh kebebasan pers, mulai muncul berbagai tabloid khusus hiburan berisi informasi selebritis, dan konten ini diadopsi menjadi tayangan televisi. Dengan demikian, pesatnya pertumbuhan infotainment didorong oleh berbagai macam faktor, mulai dari faktor ekonomi, faktor sosial, dan faktor regulasi.
Infotainment di Indonesia merupakan pasar yang sangat potensial mengingat jumlah di Indonesia, konsumen televisi memiliki jumlah terbesar disebanding media lainnya. Selain itu dari biaya produksi, infotainment tidak memerlukan biaya yang terlalu besar, teknologi yang terlalu mahal, dan kemampuan jurnalis yang rumit. Ketika dilempar di pasar pun, tayangan infotainment disambut baik dan memiliki rating yang cukup bagus. Oleh karena itulah, dalampeta industry televisi, infotainment dianggap sebagai salah satu komoditas strategis sehingga terus menerus diproduksi secara intensif. Jika dilihat dari kaca mata logika industrialisasi media, fenomena pesatnya pertumbuhan infotainment ini dapat dijelaskan melalui tiga konsep utama, yaitu Komodifikasi Media (Mosco, 2009), Standarisasi (Adorno, 1954), dan Reduksi Substansi (Postman, 1985).

Ketiga konsep tersebut membangun konstruksi pemikiran untuk memahami bahwa industrialisasi infotainment dilakukan dengan cara menjadikan infotainment sebagai suatu komoditas media yang memiliki nilai tukar dengan memanfaatkan audiens, pekerja, dan pengiklan. Kemudian, dari infotainment yang berhasil di pasaran, dirumuskan suatu formulasi standar untuk mereproduksi tayangan infotainment yang lain, dan untuk mempertahankan agar infotainment tersebut menarik minat masyarakat, dilakukanlah reduksi substansi dengan cara mengedepankan informasi yang sifatnya trivial dan sensasional.

Ketiadaan pemihakan terhadap nurani dan moralitas masyarakat sebagaimana fenomena di atas, sehingga menabrak koridor fungsi media massa, mendorong pemilik media cenderung menayangkan sesuatu yang memiliki nilai tambah di masyarakat, dengan menafikkan fungsi mendidik, memberikan informasi yang bermanfaat dan mempengaruhi masyarakat dengan pemikiran yang lebih kosmopolit. Inilah persoalan serius yang dihadapi bangsa ini, serta belum memperoleh penegakan hukum sebagaimana diatur dalam 
perundang-undangan. Dalam hal ini Komisi Penyiaran Indonesia yang telah berkali-kali menegur dan memberikan peringatan keras terhadap stasiun televisi yang menyiarkan tayangan infotainment kurang pantas, sebatas hanya menegur dan memperingati, tanpa bisa membawanya ke ranah peradilan. Kekuatan kapital yang melekat disertai kekuatan sosial politik pemilik media, membuat semua pelanggaran dan kejahatan di media massa berlangsung begitu saja tanpa pernah tersentuh hukum.

\section{DAFTAR PUSTAKA}

\section{Buku:}

Creeber, Glen (Ed). 2001. The Television Genre Book. London: British Film Institute.

Denis Mc Quail, 2011. Teori Komunikasi Massa, Jakarta. Salemba Humanika.

Gordon, A. David dan John Michael Kitross. 1999. Controversies in Media Ethics. UnitedStates: Wesley Longman Educational Publishers Inc.

Ibrahim, Idi Subandy \& Bachruddin Ali Akhmad. 2014. Komunikasi \& Komodifikasi: Mengkaji Media dan Budaya dalam Dinamika Globalisasi. Jakarta. Yayasan Pustaka Obor Indonesia.

Karimah, Kismiyati El dan Uud Wahyudin. 2010. Aspek Ontologis, Epistemologis dan Aksiologis dalam Memandang Ilmu Komunikasi. Bandung. Widya Padjadjaran.

Mosco, Vincent.2009. The Political Economy of Communication: Rethinking and Renewal Second Edition. London: Sage Publications, Inc.

Postman, Neil. 1985. Amusing Ourselves to Death: Public Discourse in the Age of Show Business. New York: Penguin Books.

Santosa, Hedi Pudjo. Menelisik Lika-Liku Infotainment di Media Televisi, Gapai Asa. Yogyakarta. Media Prima.

Strinati, Dominic. 2007. Budaya Populer: Pengantar Menuju Teori Budaya Populer. Yogyakarta: Jejak.

Sunarto. 2009. Televisi, Kekerasan \& Perempuan. Jakarta. Kompas. 


\section{Internet}

Firdaus, Iman. (2009, 19 Desember)Sejarah Infotainment dan Para Pencari Laba, diunduh dari http:/ /sosbud.kompasiana.com/2009/12/19/sejarah-infotainment-dan-para-pencara-laba/ pada 2 Januari 2012, Pukul 10.46.

Nielsen Television Audience Measurement. (2005-2009), diakses dari http://www.agbnielsen.net/ whereweare/dynPage.asp?lang=local\&id=321\&country=Indonesia pada 3 Januari2012, Pukul 12.46.Rayendra, Panditio. (2011, 5 September).

Rating Report : Kematian Istri Saipul JamilDongkrak Rating Infotainment, diunduh dari http:// www.tabloidbintang.com/film-tv-musik/ulasan/15493-rating report-kematian-istri-saipul-jamildongkrak-rating infotainment.html pada 3 Januari 2012, Pukul 13.02.Sayatman. (2010).

Etika Media dalam Keberagaman Acara Infotainment di Televisi Indonesia, diunduh darihttp:// sayatasik.multiply.com/journal/item/1?\&show_interstitial $=1 \& u=\% 2 F$ journal $\% 2$ Fitem pada 1 Januari 2012, Pukul 07.21.VivaNews.com. (2009, 27Desember).

Penonton Setia Infotainment 10 Juta Orang, diunduh dari http://nasional.vivanews.com/news/read/ 116325 penonton_setia_infotainment_10_juta_orang pada 3 Januari 2012, Pukul 20.54. 